\title{
PENGARUH PERENCANAAN KEPERAWATAN DENGAN KUALITAS KESEHATAN PASIEN
}

\author{
Kiki Dwi Febriyanti
}

Kiifeb83@gmail.com

\section{LATAR BELAKANG}

Manajemen asuhan keperawatan merupakan suatu proses keperawatan yang menggunakan konsep manajemen secara umum didalamnya seperti perencanaan, pengorganisasian, pengarahan dan pengendalian atau evaluasi. Peningkatan mutu pelayanan adalah derajat memberikan pelayanan secara efisien dan efektif sesuai dengan standar profesi, standar pelayanan yang dilaksanakan secara menyeluruh sesuai dengan kebutuhan pasien, memanfaatkan teknologi tepat guna dan hasil penelitian dalam pengembangan pelayanan kesehatan/ keperawatan sehingga tercapai derajat kesehatan yang optimal.

Sistem model asuhan keperawatan professional (MAKP) adalah suatu kerangka kerja yang mendefinisikan empat unsur yakni standar, proses keperawatan, pendidikan keperawatan, sistem MAKP. Perawat profesional dalam memberikan pelayanan keperawatan di masa depan adalah harus dapat berkomunikasi secara lengkap, adekuat dan cepat (Nursalam,
2012). Pelayanan keperawatan akan lebih memuaskan tentunya dengan penerapan model asuhan keperawatan professional atau MAKP karena kepuasan pasien ditentukan salah satunya dengan pelayanan keperawatan yang optimal (Fisbach, 1991 dalam jurnal Nur Hidayah, 2014). Untuk menilai kualitas pelayanan keperawatan diperlukan adanya standar praktik keperawatan yang merupakan pedoman bagi perawat dalam melaksanakan asuhan keperawatan yang diwujudkan dalam bentuk proses keperawatan baik dari pengkajian sampai evaluasi (Nursalam, 2008).

Salah satu cara untuk meningkatkan kualitas pelayanan keperawatan yaitu terdapat pada proses komunikasi yang baik yang dilakukan oleh perawat kepada pasien/keluarga pasien. Menurut Kuntoro (2010) bahwa manajemen keperawatan diartikan sebagai proses pelaksanaan pelayanan keperawatan melalui upaya staf keperawatan untuk memberikan asuhan keperawatan, pengobatan dan rasa aman kepada pasien/ keluarga serta masyarakat. 
Beberapa keuntungan dari metode tim dalam pemberian asuhan keperawatan adalah dapat memberikan kepuasan kepada pasien dan perawat, Pasien merasa diperlakukan lebih manusiawi karena pasien memiliki sekelompok perawat yang lebih mengenal dan memahami kebutuhannya, dan Perawat dapat mengenali pasien secara individual karena perawatannya menangani pasien dalam jumlah yang sedikit. Terdapat hubungan yang bermakna antara komunikasi dengan kepuasan pasien. Hal ini sesuai dengan (Nursalam, 2012) bahwa salah satu faktor yang mempengaruhi kepuasan pasien terdapat pada kinerja perawat dimana salah satu unsur yang ikut mempengaruhi yaitu keramahan perawat kepada pasien, Institusi pelayanan dianggap baik apabila dalam memberikan pelayanan lebih memperhatikan kebutuhan pasien misalnya keramahan dalam memberikan pelayanan keperawatan.

\section{METODE}

Metode yang digunakan dalam penulisan ini adalah metode kajian bebas dimana metode ini berwilayah lebih sempit dengan tingkat variasi yang rendah, namun dari penulisan ini dapat berkembang menjadi lebih luas. Metode kajian bebas ini merupakan metode yang dilakukan untuk melakukan penulisan yang dikumpulkan dari beberapa sumber seperti buku teks, buku referensi jurnal dan e-book, dan juga dibandingkan dengan jurnal yang berhubungan dengan "Pengaruh Perencanaan Keperawatan Dengan Kualitas Kesehatan Pasien”. Sehingga pembaca khususnya para perawat atau yang sedang mengikuti pendidikan keperawatan mengenai pentingnya perancanaan asuhan keperawatan sehingga asuhan keperawatan dapat dengan mudah dan cepat serta tepatuntuk dilaksanakan.

\section{HASIL}

Proses keperawatan merupakan suatu methode yang dilakukan oleh perawat untuk merancang asuhan keperawatan yang akan diberikan pada pasiennya. Proses keperawatan merupakan method pemberian asuhan keperawatan yang berfokus kepada pemecahan masalah kesehatan individu yang terdiri dari 5 tahapan yaitu diantaranya: tahap pengkajian,tahap diagnose,tahap perencanaan, tahap implementasi, tahap evaluasi yang dimana tahapan tahapan tersebut bertujuan sebagai pedoman perawat dalam memberikan asuhan keperawatan pada klienya. Pengkajian ini dibuat untuk mengetahui pengaruh proses keperawatan yang dilakukan terhapan perencanaan asuhan 
keperawatan yang akan diberikan. Perawat sebagai suatu profesi yang merupakan bagian dari tim kesehatan bertanggung jawab membantu klien. Pengkajian ini dilakukan dengan meriview beberapa jurnal dan literature yang relevan. Pengkajian, diagnose, rencana, tindakan, evaluasi dan pendokumentasian yang dilakukan perawat sesuai dengan standart asuhan keperawatan maka maka perencanaan asuhan keperawatan akan tersusun dengan baik sehingga akan memungkinkan perawat untuk memberikan asuhan keperawatan secara kontiniu sehingga akan membantu mempercepat kesembuhan klien dan memungkinkan klien untuk beradaptasi dengan lingkungan yang ada.

Kepuasan pasien merupakan harapan dan tujuan dari setiap institusi penyedia layanan kesehatan. Banyak usaha yang bisa dilakukan agar kepuasan pasien bisa tercapai. Salah satu upaya yang bisa dilakukan adalah dengan meningkatkan kualitas asuhan keperawatan melalui peningkatan kualitas dokumentasi asuhan keperawatan. menurut Awinda (2004) hasil beberapa survei menunjukkan bahwa mutu pelayanan yang diberikan, kecepatan pemberian layanan, prosedur serta sikap yang diberikan oleh pemberi pelayanan kesehatan itu berhubungan dengan kepuasan pasien. Hal itu didukung dengan pernyataan Suryawati (2008) bahwa kepuasan pasien banyak dipengaruhi secara langsung oleh mutu pelayanan yang diberikan rumah sakit terutama yang berhubungan dengan fasilitas rumah sakit, proses pelayanan dan sumber daya yang bekerja di rumah sakit.

\section{PEMBAHASAN}

\section{Asuhan Keperawatan}

Asuhan keperawatan adalah faktor penting dalam kelangsungan hidup pasien dan aspek-aspek pemeliharaan, rehabilitatif dan prefentif perawatan kesehatannya. Menurut Shore, untuk sampai pada hal ini, profesi keperawatan telah mengidentifkasi proses pemecahan masalah yang "menggabungkan elemen yang paling diinginkan dari seni keperawatan dengan elemen yang paling relevan dari sistem teori, dengan menggunakan metode ilmiah". Proses keperawatan ini diperkenalkan pada tahun 1950-an sebagai proses yang terdiri atas tiga tahap : Pengkajian, perencanaan dan evaluasi yang didasarkan pada metode ilmiah pengamatan, pengukuran, pengumpulan data dan penganalisaan temuan. Kajian selama bertahun-tahun, penggunaan dan perbaikan telah mengarahkan perawat pada pengembangan proses keperawatan menjadi lima langkah yang konkret (pengkajian, identifikasi masalah, perencanaan, implementasi dan evaluasi) yang memberikan metode efisien 
tentang pengorganisasian proses berfikir untuk pembuatan keputusan klinis.

\section{- Proses perencanaan Keperawatan}

Perencanaan Keperawatan adalah sebuah proses penyusunan berbagai intervensi keperawatan yang dibutuhkan untuk mencegah, menurunkan, serta mengurangi masalah-masalah klien. Perencanaan ini adalah langkah ketiga dalam membuat suatu proses keperawatan. Perencanaan merupakan bagian dari fase pengorganisasian dalam proses keperawatan sebagai pedoman untuk mengarahkan tindakan keperawatan dalam usaha membantu, meringankan, memecahkan masalah atau untuk memenuhi kebutuhan klien. Suatu perencanaan yang tertulis dengan baik akan memberi petunjuk dan arti pada asuhan keperawatan karena perencanaan adalah sumber informasi bagi semua yang terlibat dalam asuhan keperawatan klien. Perencanaan merupakan suatu petunjuk tertulis yang menggambarkan secara tepat rencana tindakan keperawatan yang dilakukan terhadap klien sesuai dengan kebutuhannya berdasarkan diagnosis keperawatan. Metode yang digunakan dalam penulisan kajian ini adalah metode pengumpulan data. Perencaaan dalam asuhan keperawatan sangat perlu untuk dilakukan agar mempermudah perawat dalam melakukan asuhan keperawatan sesuai dengan kebutuhan yang harus dipenuhi terhadap pasien. Sehingga perlu bagi perawat untuk mempersiapkan segara perencanaan asuhan keperawatan dengan benar dan tepat sehingga asuhan keperawatan dapat diberikan sesuai dengan kebutuhan pasien.

\section{Kepuasan Keperawatan}

Kepuasan pasien merupakan perasaan yang dimiliki pasien dan timbul sebagai hasil dari kinerja layanan kesehatan setelah pasien membandingkannya dengan apa yang diharapkan (Pohan, 2007). Hasil tersebut berupa respon dari pasien terhadap pelayanan kesehatan yang diterima secara nyata. Pelayanan kesehatan yang dimaksud dalam penelitian ini yakni pelayanan keperawatan. Pelayanan keperawatan yang diterima oleh pasien ternyata lebih buruk dari harapan pasien, maka pasien tersebut merasa tidak puas karena merasa kecewa. Apabila pelayanan keperawatan yang diterima oleh pasien ternyata sebanding dengan harapan pasien maka pasien merasa puas (senang). Kepuasan pasien adalah suatu prioritas yang akan membantu perawat dalam memberikan pelayanan keperawatan agar pasien mau berparisipasi selama perawatan. Menurut Peter dan Olson (2000), kepuasan pelanggan adalah 
konsep penting dalam konsep pemasaran dan penelitian konsumen. Sudah menjadi pendapatan umum bahwa jika pelanggan merasa puas dengan suatu produk atau merek, mereka cenderung akan terus membeli dan menggunakannya serta memberitahukan orang lain tentang pengalamannya yang menyenangkan dengan produk tersebut. Jika mereka tidak dipuaskan, mereka cenderung beralih merek serta mengajukan keberatan pada produsen, pengecer, dan bahkan menceritakannya kepada pelanggan lainnya. Menurut Kotler dan Keller (2009), kepuasan pelanggan (customer satisfaction) diartikan sebagai fungsi dari seberapa sesuainya harapan pembeli produk dengan kinerja yang dipikirkan pembeli atas produk tersebut. Westbrook dan Reilly juga memberikan definisi atau pengertian kepuasan pelanggan (customer satisfaction) sebagai respons emosional terhadap pengalamanpengalaman berkaitan dengan produk atau jasa tertentu yang dibeli, gerai ritel, atau bahkan pola perilaku (seperti perilaku berbelanja dan perilaku pembeli), serta pasar secara keseluruhan (dalam Tjiptono 2008).

\section{Klasifikasi Kepuasan}

Menurut Gerson (2002), untuk mengetahui tingkat kepuasan pelanggan dapat diklasifikasikan dalam beberapa tingkatan sebagai berikut :
1. Sangat memuaskan

Diartikan sebagai ukuran subjektif hasil penilaian perasaan pasien yang menggambarkan pelayanan kesehatan sepenuhnya atau sebagian besar sesuai kebutuhan atau keinginan pasien, seperti sangat bersih (untuk prasarana), sangat ramah (untuk hubungan dengan dokter atau perawat), atau sangat cepat (untuk proses administrasi), yang seluruhnya menggambarkan tingkat kualitas pelayanan yang paling tinggi.

2. Memuaskan

Diartikan sebagai ukuran subjektif hasil penilaian perasaan pasien, yang menggambarkan pelayanan kesehatan tidak sepenuhnya atau sebagian sesuai kebutuhan atau keinginan seperti tidak terlalu bersih (untuk sarana), agak kurang cepat (proses administrasi), atau kurang ramah, yang seluruhnya ini menggambarkan tingkat kualitas yang kategori sedang.

3. Tidak memuaskan

Diartikan sebagai ukuran subjektif hasil penilaian perasaan pasien rendah, yang menggambarkan pelayanan kesehatan tidak sesuai kebutuhan atau keinginan seperti tidak terlalu bersih (untuk sarana), agak lambat (untuk proses administrasi), atau tidak ramah.

4. Sangat tidak memuaskan.

Diartikan sebagai ukuran subjektif hasil penilaian perasaan pasien yang 
rendah, menggambarkan pelayanan kesehatan tidak sesuai kebutuhan atau keinginan seperti tidak bersih (untuk sarana), lambat (untuk proses administrasi), dan tidak ramah. Seluruh hal ini menggambarkan tingkat kualitas yang kategori paling rendah.

\section{Pengaruh Perencanaan Keperawatan}

\section{Dengan Kulitas Kesehatan Pasien}

Perencanaan Keperawatan adalah sebuah proses penyusunan berbagai intervensi keperawatan yang dibutuhkan untuk mencegah, menurunkan, serta mengurangi masalah-masalah klien. Kemampuan perawat dalam melakukan perencanaan atau intervensi kepada pasien adalah mempersiapkan segara perencanaan asuhan keperawatan dengan benar dan tepat sehingga asuhan keperawatan dapat diberikan sesuai dengan kebutuhan pasien. Perencanaan keperawatan meliputi perumusan tujuan, tindakan dan penilaian rangkaian asuhan keperawatan pada klien berdasarkan analisis pengkajian agar masalah kesehatan dan keperawatan klien dapat diatasi.

Rencana tindakan disesuaikan dengan standar asuhan keperawatan yang membagi karakteristik tindakan berupa : tindakan konseling, pendidikan kesehatan, perawatan mandiri dan aktivitas hidup sehari-hari, terapi modalitas keperawatan, perawatan berkelanjutan, tindakan kolaborasi (terapi somatik dan psikofarma).
Pada dasarnya tindakan keperawatan terdiri dari tindakan observasi dan pengawasan, terapi perawatan, pendidikan kesehatan dan tindakan kolaborasi.

\section{PENUTUP}

\section{Kesimpulan}

Kepuasan pasien merupakan harapan dan tujuan dari setiap institusi penyedia layanan kesehatan. Banyak usaha yang bisa dilakukan agar kepuasan pasien bisa tercapai. Salah satu upaya yang bisa dilakukan adalah dengan meningkatkan kualitas asuhan keperawatan melalui peningkatan kualitas perencanaan / intervensi asuhan keperawatan. Terdapat beberapa pengaruh dari hasil perencanaan atau intervensi yang dilakukan perawat kepada pasien. Salah satu pengaruhnya ialah, bila intervensi dilaksanakan dengan baik maka akan memberikan atau meningkatkan kepuasan pasien, sehingga kualitas kesehatan pasien dapat meningkat.

\section{Saran}

Perawat diharapkan dapat terus meningkatkan mutu pelayanan keperawatan melalui pendokumentasian asuhan keperawatan, terutama pada bagian yang masih tidak baik yaitu bagian pengkajian, perencanaan dan pencatatan asuhan keperawatan. Selain itu perawat 
juga harus meningkatkan kepuasan pasien dari aspek yang masih kurang, yaitu aspek empati kepada pasien.

\section{DAFTAR PUSTAKA}

Achmadi, L. (2015). Gambaran Tingkat Pengetahuan Perawat Dalam Penerapan Standar Asuahan Keperawatan Diruangan Rawat Inap Interna Rsud Datoe Bhinangkang. Jurnal Universitas Sam Ratulangi. Diakses Pada 30 September2016.

Astar, F., Tamsah, H., \& Kadir, I. (2018). Pengaruh Pelayanan Asuhan Keperawatan Terhadap Kepuasan Pasien Di Puskesmas Takalala Kabupaten Soppeng. Yume: Journal of Management, 1(2).

Butar-Butar, J., \& Simamora, R. H. (2016). Hubungan Mutu Pelayanan Keperawatan Dengan Tingkat Kepuasan Pasien Rawat Inap Di Rsud Pandan Kabupaten Tapanuli Tengah. Jurnal Ners Indonesia, 6(1), 50-63.

Deniati, K., Anugrahwati, R., \& Suminarti, T. (2018). Pengaruh Berfikir Kritis Terhadap Kemampuan Perawat Pelaksana Dalam
Melakukan

Asuhan

Keperawatan Di Rumah Sakit Hermina Bekasi Tahun 2016. Holistik Jurnal

Kesehatan, 12(1), 21-25.

Desimawati, D. (2013). Hubungan Layanan Keperawatan Dengan Tingkat Kepuasan Pasien Rawat Inap Di Puskesmas Sumbersari Kabupaten Jember. Jurnal Universitas Jember.

Hastuti, H. (2017). Pengaruh Intervensi Keperawatan "Cerdikk" Terhadap Pengendalian Diabetes Melitus Pada Kelompok Lansia Di Kelurahan Curug Kota Depok. Jurnal Keperawatan Respati Yogyakarta,4(2), 142147.

Koerniawan, D., Daeli, N. E., \& Srimiyati, S. (2020). Aplikasi Standar Proses Keperawatan: Diagnosis, Outcome, Dan Intervensi Pada Asuhan Keperawatan. Jurnal Keperawatan Silampari,3(2), 739-751.

Lestari, P. H., Setiawan, A., \& Widyastuti, T. (2019). Pelaksanaan Intervensi Cakupan Informasiku Melalui Pendekatan Asuhan Keperawatan Keluarga Sebagai Upaya Pencegahan Perilaku 
Seksual Berisiko Pada

Remaja. Jurnal

Ilmu

Keperawatan

Kebidanan, 11(1).

Malik, D (2014). Hubungan Tingkat

Pendidikan Perawat Dengan

Mutu Pelayanan Keperawatan

Pada Pasien Di Rumah Sakit

Daerah Kalisat Jember. Jurnal

Fik Universitas Muhammadiyah

Jember.

Nazvia, N., Loekqijana, A., \& Kurniawati,

J. (2014). Faktor Yang Mempengaruhi Kepatuhan

Pelaksanaan Sop Asuhan Keperawatan Di Icu-Iccu Rsud

Gambiran Kota Kediri. Jurnal
Kedokteran Brawijaya, 28(1), 21-25.

Nursalam. (2012). Manajemen Keperawatan. Edisi 3. Salemba Medika: Jakarta.

Simamora, R. H. (2005). Hubungan Persepsi Perawat Pelaksana Terhadap Penerapan Fungsi Pengorganisasian Yang Dilakukan Oleh Kepala Ruangan Dengan Kinerjanya Diruang Rawat Inap Rsud Koja Jakarta Utara (Doctoral Dissertation, Tesis Fik Ui, Tidak Dipublikasikan). 